2018, volume 7, issue 3

Ziółkowska, W. (2018). Innovativeness of the Polish economy in the context of sustainable development. Copernican Journal of Finance \& Accounting, 7(3), 71-88. http://dx.doi.org/10.12775/ CJFA.2018.016

\title{
INNOVATIVENESS OF THE POLISH ECONOMY IN THE CONTEXT OF SUSTAINABLE DEVELOPMENT
}

Keywords: innovations, Summary Innovation Index, Global Innovation Index, R\&D expenditure, Pearson's and Spearman's correlation coefficients.

J E L Classification: $\mathrm{H}, \mathrm{O}$.

Abstract: This paper attempts to evaluate the progress of Polish economy's innovativeness in the years 2010-2016 against the backdrop of other EU member states. While this analysis is not exhaustive, it allows to draw the opinion that the pace of the convergence process is not fast enough. Poland, despite the growth of the summary innovation index, in 2016 was ranked only as number twenty-five among so called moderate innovators. On the other hand, Lithuania, Latvia, Malta next to the Netherlands and the UK formed a group whose level of innovativeness increased the fastest. Improvement of the innovativeness of the economy requires an increase in investments, effective partnership between enterprises and academic centers, a high level of education, and scientific research. It also turns out that R\&D expenditure is too low as well. While this figure measured as spending in euro per capita improved in Poland from EUR 68.60 in 2010 to EUR 108.30 in 2016, which represents over a 50\% growth, it was still 5.5 times lower than the average for the European Union, which stood at EUR 592.30. Total R\&D outlays in 2016 in all sectors made up a mere $0.97 \%$ of the GDP, while the EU average was $2.03 \%$ of the GDP. The return rate on the outlays measured as an improvement of the summary innovation index, on the assumption that in 2010 the $U E=100$, is relatively low. The

Date of submission: November 13, 2018; date of acceptance: December 14, 2018.

* Contact information: wieslawajoanna@poczta.onet.pl, WSB University in Poznań, Powstańców Wielkopolskich 5, 61-874 Poznań, Poland, phone: +48 6165533 33; ORCID ID: https://orcid.org/0000-0002-3185-6544. 
growth of the summary innovation index in 2016, measured against the EU average in 2010 treated as 100, was the same as the average for the EU and equaled 2 points.

\section{INTRODUCTION}

The purpose of this paper is to analyze the progress of Polish economy's innovativeness as a sine qua non for its sustainable development against the backdrop of other EU member states in the years 2010-2016. Sustainable development is understood as the use of solutions based on institutional arrangements as well as ethic-and-moral governance leading to a balance among the economic, social, and ecological spheres.

The definition of innovativeness was presented for the first time by Joseph Schumpeter in 1912 (Schumpeter, 1960, pp. 103-104). He introduced a differentiation between an invention and innovation. In his opinion, an invention is a creation of knowledge, while an innovation is the implementation of an invention into production. An innovation can be understood broadly and narrowly. In its narrow aspect, an innovation is treated as something new, marketed for the first time, and usually is technical in nature. In its broader aspect, results of innovations are an important element of social reality, organizational structures, and marketing solutions, not only economic practice. Innovations understood in such a way bring benefits to the general public, not only to employers and producers, but also consumers and employees.

EU member states have different levels of wealth expressed in GDP measured as purchasing power parity per capita. In the years in question, the countries with the highest average income ranging from PPS 53,300 to 36,000 per capita were Ireland, the Netherlands, Austria, Denmark, Sweden, and Germa$n y^{1}$. In the second group of countries with the lowest per capita income from PPS 19,700 to 14,200 were: Greece, Hungary, Latvia, Croatia, Romania, and Bulgaria. Poland, with per capita income at PPS 19,900 was ranked number 7 in it. Among the solutions driving sustainable development of paramount importance is the improvement of EU economies in terms of innovativeness and competitiveness, as this is the only way that offers a chance to reduce differences in the level of wealth of societies and their quality of life.

Building a new "order" is not easy. It must be recognized that neither globalization, nor the evolution of industrial capitalism into a financial one, and

${ }^{1}$ Luxembourg was not included to its specificity. 
the associated atomization of money from the real zone, are not processes regulated easily. But although sustainable development on a global and regional scale may seem too difficult for some theorists and practitioners, it should not be abandoned but should be treated as a benchmark for alternative solutions moving towards its direction.

\section{THE RESEARCH METHODOLOGY AND THE COURSE OF THE RESEARCH PROCESS}

The theoretical part uses book publications, papers and reports, while the statistical part uses data from Eurostat, the World Bank and Polish Central Statistical Office (GUS). Different research methods were applied: qualitative and statistical analysis, and graphical presentation of data.

\section{INNOVATIVENESS AND THE ECONOMIC GROWTH}

In comparison with other Central and Eastern European countries, Polish economy is characterized by relatively good macroeconomic foundations, including slow, albeit stable growth and low scale of external imbalance. Polish public debt compared to GDP, despite going up by 3 percentage points in 2016 vs. 2015, with a decline of average share of debt in the EU over the same period by 1.3 percentage points, was lower than the average for the EU by 29.1 percentage points. The government budget balance, after the procedure of excessive deficit was imposed twice on Poland since 2015, does not exceed $-3 \%$ of GDP. The key driver of economic growth in 2016-2017 was internal consumption fueled by the implementation of the " $500+$ Program". In the longer term, once this factor has waned, the economic growth will decline from respectively $3.8 \%$ and $4.6 \%$ in 2016 and 2017, to $2.9 \%$, i.e. below the long-term average. The rate of growth of gross fixed capital formation is also too slow, coupled by a negative contribution of net exports to growth. The impact of external economic situation on economic growth in Poland is also unclear. In 2017 imports increased by $12.3 \%$, while exports by $10.2 \%$, in comparison with the previous year. Faster import growth resulted mainly from higher consumption, increase of oil prices, and appreciation of the Polish zloty. What raises the most concern is gross fixed capital formation which in 2015 was still 0.6 percentage points higher than in EU 28, while in 2016 it went down by 1.7 percentage points to $18.1 \%$ GDP, at the EU average at 19.8\% GDP. The rate of growth in corporate investment, despite closing the output gap and growing demand, may change 
very slowly due to uncertainty about tax increases and growing political risk (Inflation Report - March 2017).

However, this relatively favorable picture of the Polish economy should not be too reassuring. In 2015 and 2016 GDP per capita was PPS 68 on the assumption that the average gross domestic product of the $\mathrm{EU}=100$, while in 2005 it represented only half of it. The progress we have made in the past quarter of a century is visible but has been achieved mainly thanks to the implementation of technologies and simple economic and organizational patterns from developed countries. The pace of change in the level of innovativeness and competitiveness of the Polish economy, although visible, is very slow. Meanwhile, studies indicate the existence of a strong positive relationship between the gross domestic product and the summary innovation index. This is illustrated by the following correlation scatter plot.

Figure 1. Average GDP in PPS'000 per capita and average Summary Innovation Index in 2010-2016

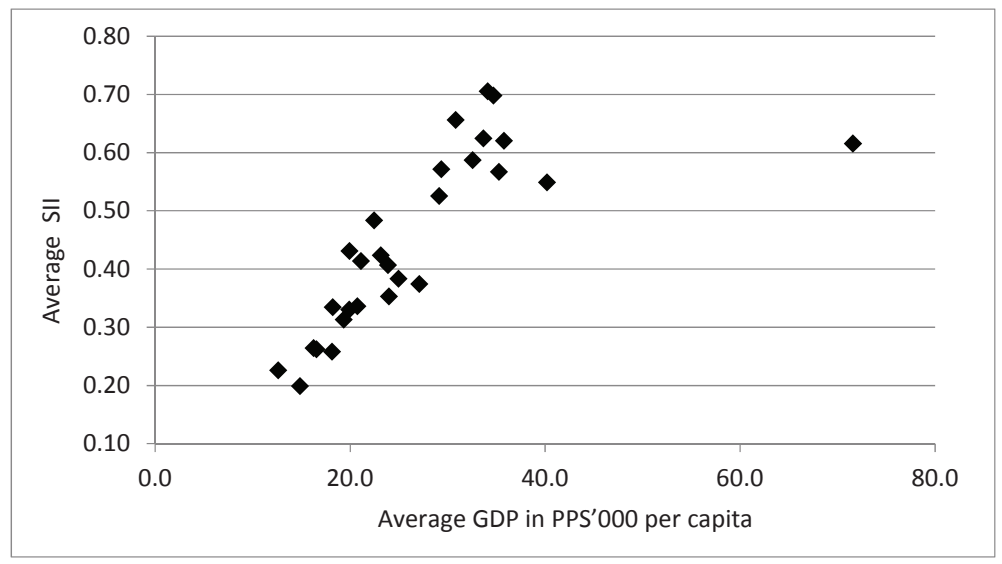

S o u r c e : own compilation on the basis of the European Innovation Union Scoreboard, 2017.

The importance of this relationship is confirmed by the Spearman's rank correlation coefficient, whose score of 0.90 falls at the turn of the fourth and fifth range of the five-point scale. However, the simple reserves of economic growth have been exhausted and, moreover, soon we will be able to benefit less and less from such significant EU funds. It is therefore necessary to change the main function of EU funds from "pro-demand to pro-supply", which can only be 
created by increasing innovativeness and competitiveness of the Polish economy. Figure 2 presents changes in the rate of growth of GDP, public debt burden, investments, and deficit as a share of GDP in Poland against average EU figures in 2010-2016.

Figure 2. GDP growth, public debt, deficit and fixed assets as a share of GDP in Poland and UE-28*

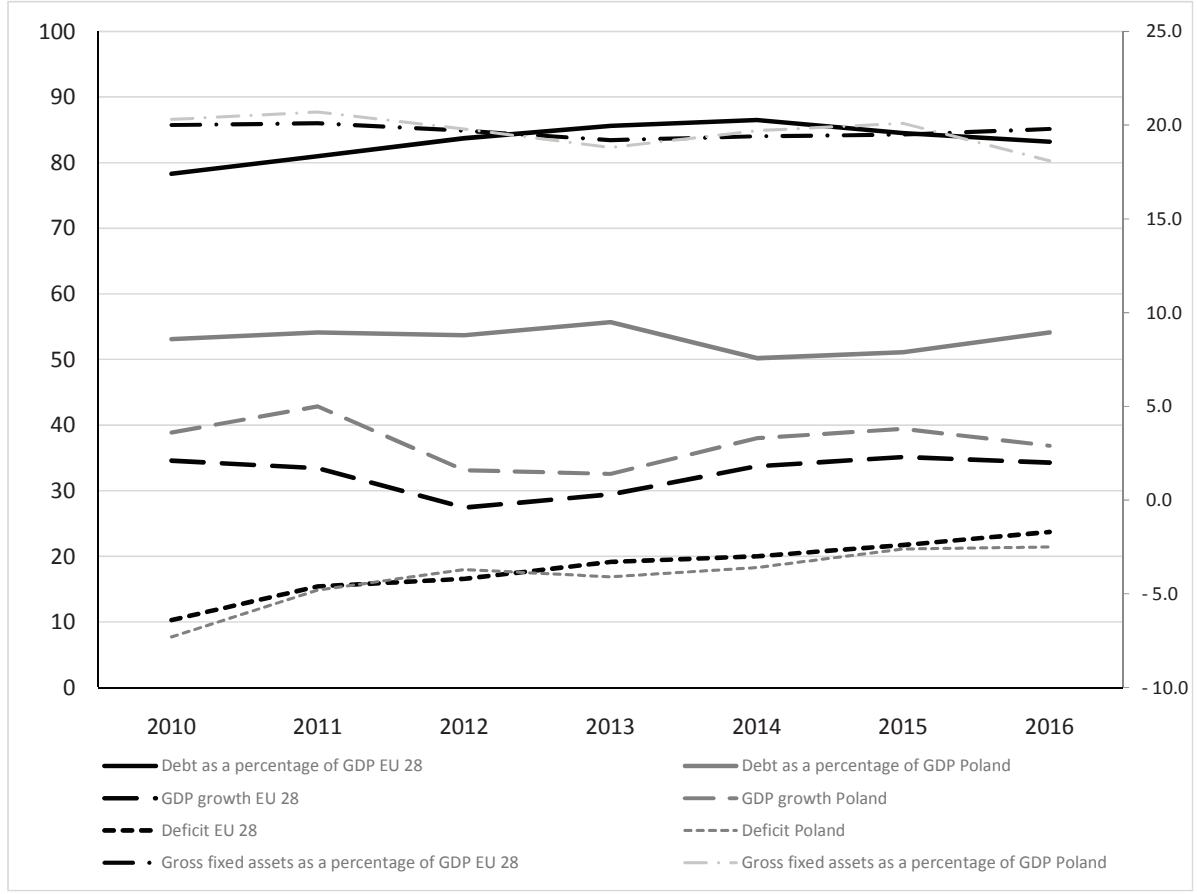

* Left scale applies to debt as a share of GDP, right scale - other measures.

S o u r c e : Eurostat, 2017.

\section{KEY MEASURES OF ECONOMIC DEVELOPMENT}

Current economy is characterized by a departure from industrialism towards an economy based on the human potential, and a high technological level. The position of every country in the world illustrating the scale of its economic, technological and cultural development can be determined using various in- 
dicators. In practice there are over 50 such indicators, the most popular of which are: the Human Development Index (HDI), Networked Readiness Index (NRI), Social Progress Index (SPI), and the Digital Economy and Society In$\operatorname{dex}(\mathrm{DESI})$.

The Human Development Index (HDI) describes the level of a country by evaluating it using partial indicators, and three key ones, namely long and healthy life, education, and decent standard of living. In this comparison Norway ranks highest, while out of countries which joined the EU after 2004: the Czech Republic, Estonia, Slovakia, and Poland (number 36 in the general ranking). The index has many different modifications. In Poland, the most popular indicators are the poverty indicator, social exclusion, and social marginalization.

The next indicator, NRI, was created for the needs of the World Economic Forum. The key purpose of the NRI is to measure trends of countries to use innovative information and telecommunication technologies. It uses 68 pieces of data grouped in ten categories. The development of Poland measured with that indicator in 2015 ranked it as number 50, with Singapore being number one.

The global Social Progress Index (SPI) was created on the basis of analyzing individual indicators obtained from 133 countries which relate to the main aspects of the functioning of society, namely:

- fundamental human needs, e.g. safe shelter and access to water,

- health care,

- social advancement opportunities, and personal freedoms.

In the 2017 ranking Denmark scored number one, while Poland was ranked 32. What was scored high was, inter alia, citizens' personal safety, while low scores were given for the level of availability of affordable housing. As in the case of other Central European countries, Poland received a relatively low score for tolerance of immigrants, and recognition of minority rights.

The indicator which evaluates the economy and society from the point of view of digitization is DESI. Its calculation is based on over 30 coefficients grouped into five categories: human capital, communications, Internet usage, digital technology integration, and digital public services. In 2017 the value of DESI for Poland was 0.43, which ranked it as 23, while the average for the EU was 0.52 , and Denmark at the top of the ranking and scoring 0.71 .

In each of the indicators listed above, innovativeness plays and important role, and in it broadly understood human capital. However, there is no generally applicable measure of innovativeness. The author, as in the "Frascati Manual" (OECD, 2002), assumes that research and development (R\&D) consists of 
systematically conducted creative work undertaken to increase knowledge and find new applications for it ${ }^{2}$. This creative work reflects different levels of knowledge gained not only during a formal tuition process, but also stemming from experience. The divisions of innovations and drivers standing behind them have been discussed at length in literature and studies, not only foreign, but also Polish ones (Balcerowicz \& Wziątek-Kubiak, 2009; Kozioł, 2007; Francik \& Pocztowski, 1991; Poznańska, 1998). The complexity of the issue makes its examination a difficult process. The measurement of innovativeness of different economies requires interdisciplinary knowledge and experience.

In Europe, the predominant indicator used to measure the potential of innovativeness of economies is the Summary Innovation Index (SII) published in the European Innovation Scoreboard (EIS). Since the methodology of computing the SII measure has evolved over the years, data preceding 2010 can be compared only to a limited extent with data from years 2010-2016.

The European Innovation Scoreboard is an annual report evaluating innovation achievements of EU member states on the basis of the SII. The SII is calculated as a weighted arithmetic mean of 29 individual indicators for $28 \mathrm{EU}$ states and Turkey, Iceland, Norway, Switzerland, USA, and Japan. The SII ranges from 0 to 1, which higher scores indicating a higher level of innovativeness for a given country. The SII takes into account individual indicators covering both spending on innovations and their outcomes ${ }^{3}$. The former are described by measures showing funding, education, corporate investment, and infrastructure in which they operate. The latter, on the other hand, relate mainly to economic outcomes of enterprises implementing innovations (WołodkiewiczDonimirski, 2011, pp. 9-33).

Innovativeness is also measured by the Global Innovation Index (GII) developed in 2007 (The Global Innovation Index 2014: The Human Factor in Innovation). At present is measures innovativeness of 127 economies in the world using 81 indicators. The measures comprised in this indicator can be divided into two main groups:

- factors creating innovativeness (innovation input) covering institutions, human potential, ICT and infrastructure, market sophistication, business sophistication;

2 "Frascati Manual" is the first methodological manual with guidelines for statistical research in science and technology (OECD, 2002).

3 The number of indicators in individual reports varied from 22 to 30 . 
- innovation activities' outcomes (innovation output), covering knowledge and technology outputs, and creative outputs.

For years, top positions among global innovators measured using the GII have been held by Switzerland, Sweden, the Netherlands, USA, United Kingdom, and Denmark. In 2017 the highest score was 67.69 for Switzerland, which was over 4 times higher than the lowest index given to Yemen (15.64). Poland, scoring 41.99 was ranked 38, one place up on the previous year, and ranked 25 among European countries. The GII methodology also enables the identification of strong and weak EU member states, including also Poland with respect to individual innovation indicators. Poland's innovation creation strength lies predominantly in the number of students.

On the other hand, Polish economy's weaknesses, in terms of innovativeness, cover: negligible electronic access to public services, very low quality of public infrastructure (ICT and infrastructure), ineffective law, and high regulatory burden (institutions), as well as low inclination for cooperation within clusters (sophistication of business environment/ innovation ecosystem).

\section{INNOVATIVENESS OF THE POLISH ECONOMY}

Taking the SII as the main measure of innovation and competitiveness, EU countries were divided into four groups ${ }^{4}$. Countries by group and differences among them in 2016 are presented in figure 3.

4 Taking the SII as a criterion - as per the Innovation Union Scoreboard - the countries were divided into four groups:

- innovation leaders, covering countries with a score over $120 \%$ of the average indicator for the UE,

- innovation followers, with countries whose SII ranges from $90 \%$ to $120 \%$ of the EU average,

- moderate innovators, applying to countries whose score ranges from $50 \%$ to $90 \%$ of the EU average,

- and modest innovators, whose Summary Innovation Index is under 50\% of the EU average. 
Figure 3. SII in EU countries in 2016 vs. UE 2010

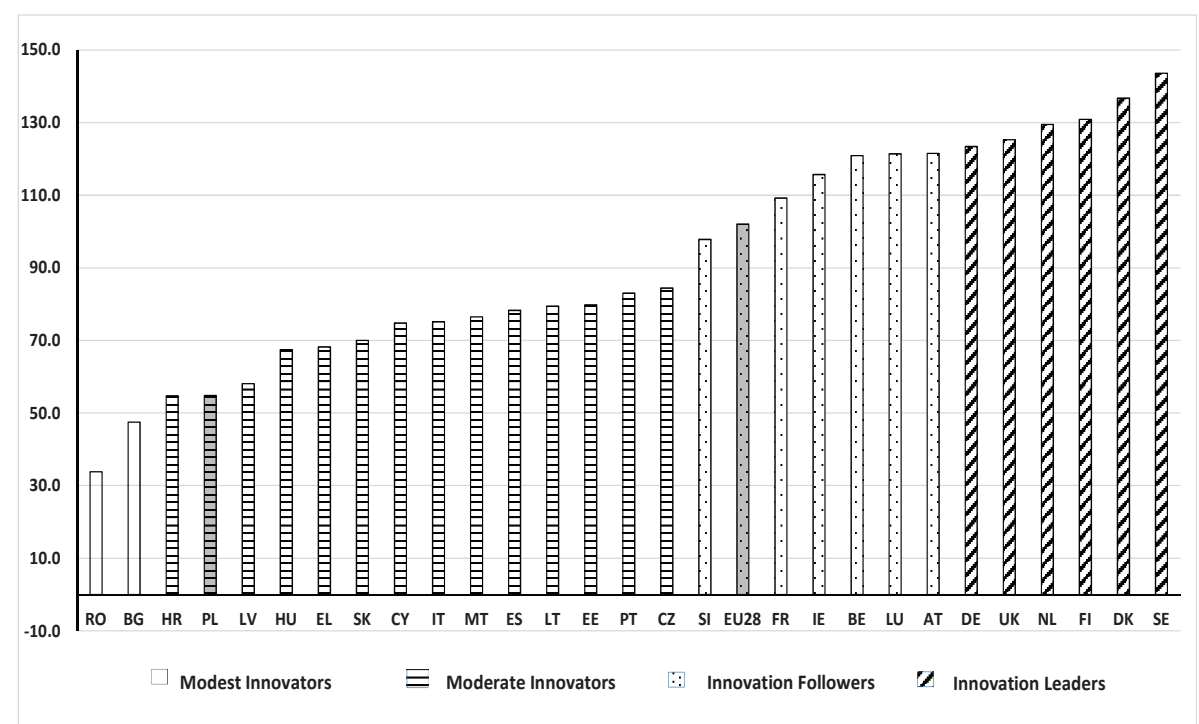

S o u r c e : European Innovation Scoreboard 2017.

Poland found itself in the third group, with its indicator in 2016 vs. UE $2010=100$ at 54.8 . The SII shows fluctuations, rather than a growing trend. For example, after an insignificant upturn in 2010-2011 there was a marked decline in 2012-2014, followed by an increase to 0.270 only in 2016 .

How innovation measured by the cumulative SII was changing in different EU economies is illustrated by the total change of the index by year, as presented in table 1.

A negative cumulative SII change appeared in as many as 13 countries and most probably was due to the economic downturn in 2008-2013. The difference between the highest and lowest index change was over 35 points. The economies of Sweden, Denmark, Finland, and the Netherlands enjoy the highest SII. These countries are also leaders in R\&D spending and high GDP per capita growth. On the other hand, the fastest growing innovators comprised Lithuania, Malta, the United Kingdom, and the Netherlands. Moreover, the difference between the highest and lowest SII, which in 2010 was 0.461 point, in 2016 increased to 0.541 point. This means, that instead of speeding up the convergence process of EU economies they started to differentiate. 
Table 1. Cumulative change of the summary innovation index in the EU in the years 2010-2016

\begin{tabular}{|c|c|c|c|c|c|c|c|c|c|c|c|c|c|c|c|}
\hline 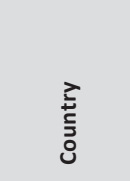 & 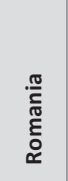 & $\frac{n}{3}$ & 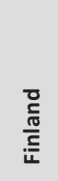 & 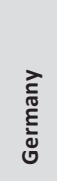 & 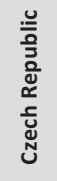 & 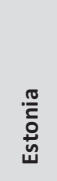 & 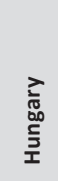 & 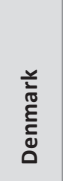 & 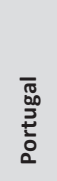 & $\begin{array}{l}\text { 产 } \\
\text { कू }\end{array}$ & 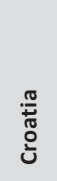 & $\frac{2}{\bar{\Phi}}$ & $\begin{array}{l}\frac{\pi}{\bar{T}} \\
\frac{\partial}{\omega} \\
\frac{0}{n}\end{array}$ & $\begin{array}{l}\frac{\pi}{2} \\
\frac{\pi}{\pi} \\
\frac{0}{5} \\
\frac{0}{5}\end{array}$ & $\begin{array}{l}\stackrel{\Xi}{\Xi} \\
\text { जँ }\end{array}$ \\
\hline $\begin{array}{l}\text { Cumulative } \\
\text { change } \\
2010-2016\end{array}$ & -14.1 & -12.7 & -5.2 & -3.7 & -3.5 & -3.5 & -3.5 & -2.8 & -2.4 & -1.8 & -1.4 & -0.3 & -0.2 & 0.1 & 0.7 \\
\hline
\end{tabular}

\begin{tabular}{|c|c|c|c|c|c|c|c|c|c|c|c|c|c|c|}
\hline 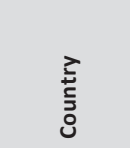 & $\frac{\xi}{\frac{\xi}{\omega 0}}$ & 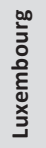 & $\stackrel{\infty}{\text { ș }}$ & $\begin{array}{l}\frac{0}{c} \\
\frac{\pi}{\pi} \\
\frac{0}{0}\end{array}$ & 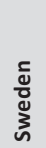 & 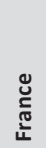 & $\begin{array}{l}\text { D } \\
\frac{\mathrm{C}}{\pi} \\
\frac{\pi}{0}\end{array}$ & $\begin{array}{l}\frac{\pi}{\frac{\pi}{\pi}} \\
\frac{0}{n}\end{array}$ & $\sum_{\text {స్ }}^{\frac{\pi}{\sigma}}$ & 竞 & 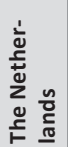 & 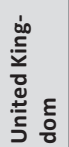 & $\frac{\frac{\pi}{ \pm}}{\sum^{\pi / 2}}$ & 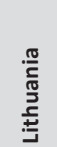 \\
\hline $\begin{array}{l}\text { Cumulative } \\
\text { change } \\
2010-2016\end{array}$ & 1.3 & 1.4 & 2.0 & 2.0 & 2.3 & 2.8 & 3.5 & 8.0 & 8.5 & 9.0 & 10.4 & 11.7 & 12.1 & 21.1 \\
\hline
\end{tabular}

S o u r c e : own calculation on the basis of the European Innovation Union Scoreboard, 2017.

An economy's ability to absorb innovations depends on many factors. The key innovation drivers consist of financial outlays on research and development, and on human capital. The most important measure of R\&D expenditure is GERD (Gross Domestic Expenditure on R\&D) ${ }^{5}$. According to the Frascati Manual GERD covers internal outlays on research and development on the territory of a country taking place in a specific year. In order to determine the strength and direction of the correlation between R\&D expenditure and GDP growth the author decided to apply statistical analysis. The following results were obtained with the use of Pearson's coefficient:

- no relationship or very poor correlation appeared in 6 countries: Estonia, Italy, Portugal, Cyprus, Czech Republic and Spain;

- in three countries the correlation was moderate: in Greece and Slovenia negative, and in Latvia positive;

${ }^{5}$ R\&D expenditure is also measured using GBAORD (Government Budget Appropriations or Outlays for Research and Development). However, GBAORD data apply to the year for which budget appropriations were planned, while GERD records the year in which they were actually spent. 
- in the 18 other countries it was strong or very strong, including in one case - Finland - negative. In Poland a very strong positive correlation took place, which means that the higher the spending of all sectors on R\&D, the higher the GDP per capita growth.

Pearson's linear correlation was also used to study the correlation between GDP per capita growth and the number of scientific researchers employed in R\&D, with the following results:

- no relationship or very poor correlation appeared in 7 countries: Italy, Portugal, Estonia, Czech Republic, Slovakia, Slovenia, and Romania;

- in two countries the correlation was moderate: Croatia and Malta;

- in the 18 other countries it was strong or very strong, including in three cases negative: Finland, Greece, and Cyprus. In Poland a very strong positive correlation took place, which means that the more scientific employees were employed in the R\&D sector, the higher the GDP per capita. According to European Commission's Europe 2020 strategy, one of the main targets of the Community is to invest 3\% of GDP in research and development by the year 2020. It is also highlighted that one-third of R\&D expenditure is to be financed from public funds of member states, while two-thirds from private sources. The forecast for Poland, based on different variants of allocating structural funds in the years 2013-2020, determined the target value of GERD in relation to GDP for Poland at 1.7\%, assuming at the same time that the government and private sectors will have equal shares in the financing.

Public funds in a direct way determine the innovativeness of economies by financing research and development activities, but also indirectly, by outlays on education, health, infrastructure, and security. The need of state's engagement in the creation of conditions for the development of R\&D activities in the modern world - in particular in economies with a low level of development - is indisputable.

From the perspective of sources of funds, they are divided into five sectors: funds of government entities (from the state budget and local government budgets), higher education, enterprises, private non-commercial institutions, and the foreign sector. The participation of these sectors differs by country significantly. R\&D is financed under statutory activity, and through grants, contracts, and subsidies. 
Table 2. R\&D expenditure and summary innovation indexes in EU countries

\begin{tabular}{|c|c|c|c|c|c|}
\hline \multirow{2}{*}{ Country } & \multicolumn{3}{|c|}{ Average GERD as a percentage of GDP in 2010-2016 } & \multirow{2}{*}{$\begin{array}{c}\text { SII } \\
2017\end{array}$} & \multirow{2}{*}{$\begin{array}{c}\text { SII } \\
2016 \text { vs. } \\
\text { UE2010 }=100\end{array}$} \\
\hline & all sectors & enterprise sector & $\begin{array}{l}\text { government } \\
\text { sector }\end{array}$ & & \\
\hline EU28 & 2.00 & 1.27 & 0.24 & 0.503 & 102.000 \\
\hline Belgium & 2.31 & 1.60 & 0.20 & 0.597 & 120.900 \\
\hline Bulgaria & 0.69 & 0.44 & 0.19 & 0.234 & 47.500 \\
\hline Czech Republic & 1.74 & 0.97 & 0.33 & 0.416 & 84.400 \\
\hline Denmark & 2.94 & 1.91 & 0.07 & 0.675 & 136.700 \\
\hline Germany & 2.85 & 1.93 & 0.41 & 0.609 & 123.400 \\
\hline Estonia & 1.71 & 0.90 & 0.17 & 0.393 & 79.800 \\
\hline Ireland & 1.45 & 1.02 & 0.07 & 0.571 & 115.700 \\
\hline Greece & 0.80 & 0.29 & 0.21 & 0.337 & 68.200 \\
\hline Spain & 1.27 & 0.67 & 0.24 & 0.386 & 78.300 \\
\hline France & 2.23 & 1.43 & 0.29 & 0.539 & 109.200 \\
\hline Croatia & 0.79 & 0.37 & 0.20 & 0.270 & 54.700 \\
\hline Italy & 1.28 & 0.72 & 0.18 & 0.371 & 75.100 \\
\hline Cyprus & 0.47 & 0.10 & 0.07 & 0.369 & 74.800 \\
\hline Latvia & 0.62 & 0.18 & 0.16 & 0.287 & 58.100 \\
\hline Lithuania & 0.92 & 0.27 & 0.18 & 0.391 & 79.400 \\
\hline Luxembourg & 1.33 & 0.76 & 0.36 & 0.599 & 121.400 \\
\hline Hungary & 1.27 & 0.87 & 0.19 & 0.332 & 67.400 \\
\hline Malta & 0.71 & 0.41 & 0.06 & 0.378 & 76.500 \\
\hline The Netherlands & 1.93 & 1.07 & 0.23 & 0.639 & 129.500 \\
\hline Austria & 2.92 & 2.06 & 0.14 & 0.599 & 121.500 \\
\hline Poland & 0.88 & 0.38 & 0.21 & 0.270 & 54.800 \\
\hline Portugal & 1.36 & 0.64 & 0.09 & 0.409 & 83.000 \\
\hline Romania & 0.45 & 0.19 & 0.18 & 0.167 & 33.800 \\
\hline Slovenia & 2.31 & 1.73 & 0.32 & 0.482 & 97.800 \\
\hline Slovakia & 0.82 & 0.32 & 0.21 & 0.345 & 70.000 \\
\hline Finland & 3.27 & 2.24 & 0.28 & 0.646 & 130.900 \\
\hline
\end{tabular}


Table 2. R\&D expenditure...

\begin{tabular}{|c|c|c|c|c|c|}
\hline \multirow{2}{*}{ Country } & \multicolumn{3}{|c|}{ Average GERD as a percentage of GDP in 2010-2016 } & \multirow{2}{*}{$\begin{array}{c}\text { SII } \\
2017\end{array}$} & \multirow{2}{*}{$\begin{array}{c}\text { SII } \\
2016 \text { vs. } \\
\text { UE } 2010=100\end{array}$} \\
\hline & all sectors & enterprise sector & $\begin{array}{l}\text { government } \\
\text { sector }\end{array}$ & & \\
\hline Sweden & 3.25 & 2.23 & 0.13 & 0.708 & 143.600 \\
\hline United Kingdom & 1.66 & 1.07 & 0.13 & 0.618 & 125.300 \\
\hline
\end{tabular}

S o u r c e : own calculation on the basis of the European Innovation Union Scoreboard, 2017.

Table 2 presents the intensity of R\&D in 2010-2016, i.e. the average share of internal GDP spending in Poland, average in the EU, by member state in total, and the share in them of the two main sectors, as well as changes of the innovation index in 2016 vs. 2010, treated as 100, and value of SII in 2017. In 2010 the highest share of GERD in GDP in Finland was over 8 times higher than the lowest one in Romania. In 2016 the same relation was lower and was under 6-fold. In 2010, in Poland, R\&D expenditure was over 5 times lower than in Finland. In 2016 this relation did not exceed the factor of 3 . However, this improvement was caused by a decline in spending in Finland by 0.98 percentage point of GDP, coupled by an increase in Poland by 0.25 percentage point. Poland recorded also an improvement compared to average spending in the EU in the first and last years of the period. While in 2010 the spending was over 2.7 times lower, in 2016 the share of expenditure according to GERD as a percentage of GDP was 2.1 times lower than the EU average.

R\&D expenditure in Poland has been increasing over the recent years. Moreover, no decline in expenditure as a share in GDP was reported in the years of the last crisis. Despite this spending the level of R\&D expenditure as a percentage of GDP still remains relatively low. In 2015 in Poland it made up 1.00\%, while in $20160.97 \%$ of gross domestic product. The average for total European Union was $2.00 \%$ of gross domestic product. However, European innovation leaders allocated significantly more on R\&D: $3.27 \%$ of GDP in Finland, $3.25 \%$ of GDP in Sweden, 2.94\% of GDP in Denmark, $2.85 \%$ of GDP in Germany, and $2.92 \%$ of GDP in Austria. GERD's response to the crisis differed country by country, and in nine countries its average change was negative. However, it impacted to a larger extent the funding of R\&D in highly developed countries.

In 2016, similarly to Poland, GERD did not exceed the level of $1 \%$ in Cyprus, Malta, Romania, Bulgaria, Latvia, Slovakia, Lithuania, and Croatia. The 3\% 
threshold specified for this indicator was achieved only by Sweden, and Austria. An analysis of the sources of funding R\&D activities shows that in countries with a higher share of GERD in GDP the level of government spending is lower.

A much more diversified picture of research and development spending in different countries we receive when we measure the spending per capita. In Finland, country with the highest R\&D expenditure in the European Union in 2010, the average GERD per capita was 46 times higher than in Romania, country with the lowest expenditure. In 2016 this relation reduced to 26 times. One must note, however, that since 2011 the first place measured by R\&D expenditure in euro per capita has been taken by Sweden, and when this country and Romania are compared the relation is reduced to 37 times.

In Poland in 2010 the value of internal expenditure on R\&D per capita was EUR 68.6, vs. the average for UE-28 at EUR 490.9. Correspondingly, in 2016 GERD per capita in Poland was EUR 108.3, while the EU average was EUR 592.3. Consequently, while the difference between Poland's the share of R\&D expenditure as a percentage of GDP and the average for the EU was not so striking, as the expenditure in Poland in 2016 was 2.3 times lower than in EU, the value of this expenditure measured in euro per capita in the last of the studied years was nearly 5.5 times lower than the EU average.

In accordance with the strategy adopted by the $\mathrm{EU}$, the share of private funding in financing R\&D should rise, while the share of public funding should decline. In the years 2010-2016 the average total EU GERD as a percentage of GDP increased by 0.10 percentage point, with an increase of enterprise funding by 0.13 percentage point, and decrease of the share of government funds by 0.02 percentage point. In Poland, while the share of expenditure of all sectors changed by 0.25 percentage point, respectively, the expenditure of enterprises went up by 0.44 percentage point of GDP, while the government sector declined by 0.24 percentage point of GDP. Figure 4 presents changes in shares of key financing sources. 
Figure 4. GERD changes as a percentage of GDP in the years 2010-2016

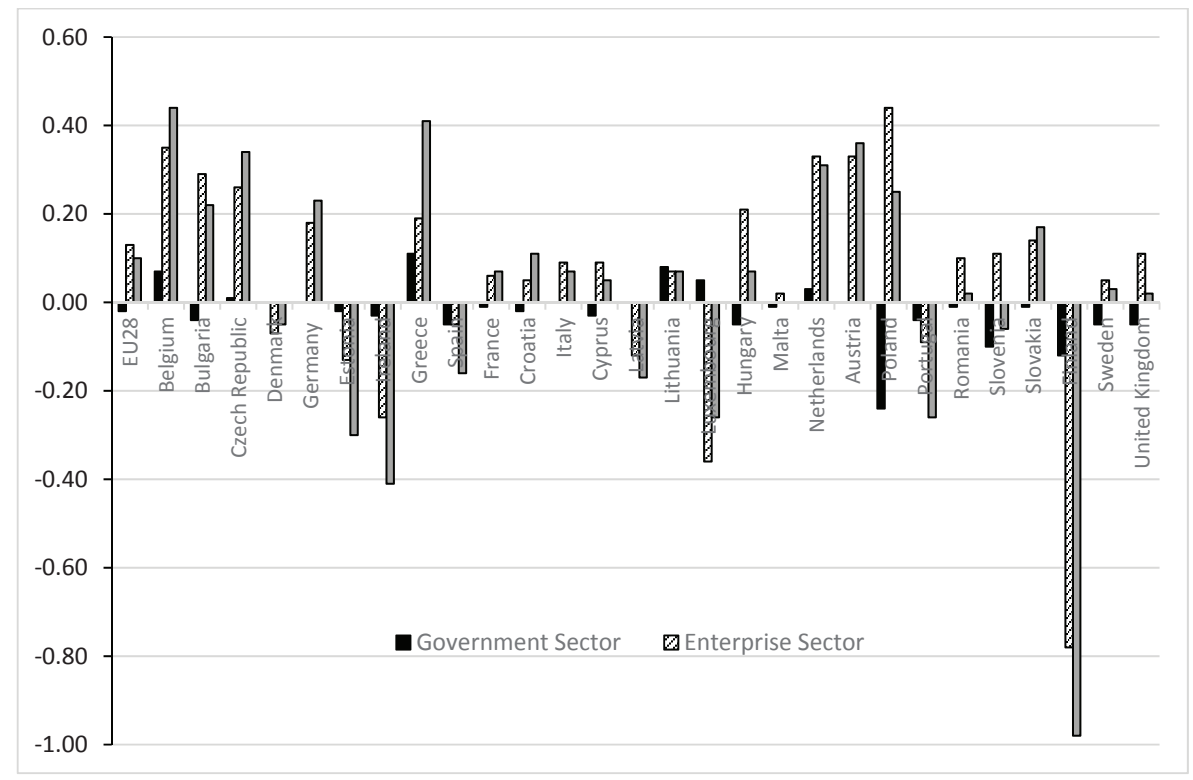

S o u r c e : own calculation on the basis of Eurostat, 2017.

The next thing that was studied was the relation between average R\&D expenditure and average GDP in PPS'000 per capita.

The figure shows a positive relation between the analyzed variables, whose strength calculated using the Spearman's rank correlation coefficient turned to be very high. For the countries of all EU it was 0.91, while for Central and Eastern Europe it was 0.60. This weaker relationship between the studied variables for countries which joined the EU in 2004 and later is caused by the fact that the effectiveness of R\&D expenditure depends on the achieved level of development measured as GDP per capita. This is confirmed by empirical data from countries with the highest innovativeness potential, like Denmark, Sweden, Finland, or Germany. This higher GERD "rate of return" measured by GDP per capita, given a higher level of the development of a country is naturally the result of different economy structures, development strategies, and many other interrelated factors. One of the reasons is believed to be a higher share of private funds in R\&D expenditure in countries with a higher GDP per capita, where allocation can be more efficient due to stronger motivation and more effective instruments to measure and control them. One cannot ignore 
this argumentation, nor can it be overestimated. The result of the study based on Spearman's coefficient, in which the variable is total GERD expenditure, is very close to the strength of the studied relationship only for public spending. Thus, the explanation of this difference based on the assumption that public policy in highly developed economies is usually more innovation focused could be more significant. Furthermore, with a higher level of economic development R\&D expenditure is naturally to a higher extent aimed at more profitable enterprises.

Figure 5. Relation between average GDP in PPS'000 per capita and average GERD expenditure as a percentage of GDP in the years 2010-2016 in EU

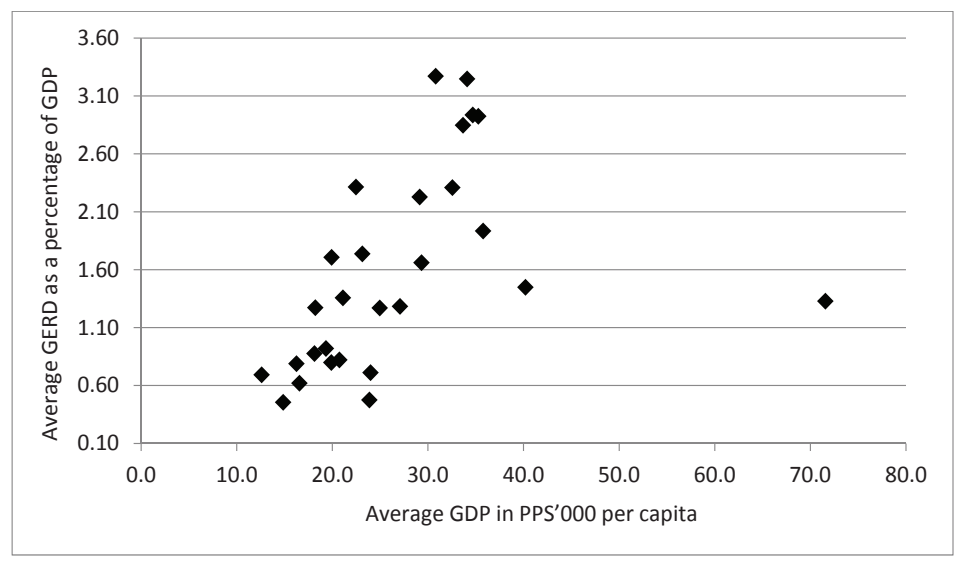

S o u r c e : own calculation on the basis of Eurostat, 2017.

\section{ConClusions}

The conducted study is far from being complete, however, it allows for the following conclusions:

1. The study based on Spearman's coefficient showed the existence of a strong correlation between the average SII and GDP in PPS'000 per capita, and between GERD spending and GDP in PPS'000 per capita.

2. In 2016 Poland belonged to the group of, so called, moderate innovators, holding the 25 th place.

3. In terms of accumulated SII growth in 2010-2016 Poland was ranked number 11. 
4. Research and development expenditure, while on the rise, is still too low. Measured in euro per capita, in 2016 in Poland it was 5.5 lower than EU average, while GDP per capita was 2.6 times lower.

5. In accordance with the presented assumptions, in Poland spending of the enterprise sector was growing faster, although still R\&D expenditure is mainly funded by the government sector.

6. A lower return rate on such R\&D expenditure is the result of a combination of different factors ranging from historical, through political, to psychological. However, a special role in this process is played by the structure of the economy, the adopted model of its development, and the broadly understood quality of human potential.

\section{REFERENCES}

Balcerowicz, E., \& Wziątek-Kubiak A. (2009). Determinanty rozwoju innowacyjności firm $w$ kontekście poziomu wykształcenia pracowników. (Company Innovativeness Development Drivers in the Context of Employee's Level of Education. Warszawa: CASE.

European Innovation Scoreboard 2017. http://ec.europa.eu/growth/industry/innovation/facts-figures/scoreboards/files/ius-2017en.pdf (accessed: 03.03.2018).

Eurostat, http://ec.europa.eu/eurostat/tgm/table.do?tab=table\&init=1\&plugin=1\&lang uage $=$ en $\&$ p code $=$ tec00127 (accessed: 14.02.2018).

Eurostat, http://ec.europa.eu/eurostat/tgm/table.do?tab=table\&init=1\&plugin=1\&la nguage $=$ en $\&$ pcode $=$ tec00011 (accessed: 16.02.2018).

Eurostat, http://appsso.eurostat.ec.europa.eu/nui/show.do?dataset=nama_10_pc\&lang=en (accessed: 01.03.2018).

Eurostat, http://appsso.eurostat.ec.europa.eu/nui/show.do?dataset=rd_e_gerdtot\&lang=en (accessed: 03.03.2018).

Eurostat, http://ec.europa.eu/eurostat/tgm/table.do?tab=table\&init=1\&plugin=1\&lang uage $=$ en \&pcode $=$ tec00001 (accessed: 02.03.2018).

Francik, A., \& Pocztowski, A. (1991). Procesy innowacyjne. (Innovative Processes.) Kraków: Akademia Ekonomiczna w Krakowie.

Inflation Report - March 2017. National Bank of Poland.

Kozioł, K. (2007). Innowacyjność polskich przedsiębiorstw przemysłowych na tle doświadczeń Unii Europejskiej. Szczecin: Wydawnictwo Uniwersytetu Szczecińskiego.

OECD (2002). Frascati Manual. Proposed Standard Practice for Surveys on Research and Experimental Development, http://www.nauka.gov.pl/g2/oryginal/2013_05/0 8935db1c9f7adf15c087d07720a984f.pdf (accessed: 11.11.2014).

Poznańska, K. (1998). Uwarunkowania innowacyjności małych i średnich przedsiębiorstw. (Innovativeness Determinants of Small and Medium Enterprises.) Warszawa: Dom Wydawniczy ABC. 
Schumpeter, J.A. (1960). Teoria rozwoju gospodarczego. (Theory of Economic Development.) Warszawa: PWN.

The Global Innovation Index 2014: The Human Factor in Innovation. http://www. globalinnovationindex.org/userfiles/file/reportpdf/GII-2014-v5.pdf (accessed: 20.11.2014).

Wołodkiewicz-Donimirski, Z. (2011). Innowacyjność polskiej gospodarki na tle międzynarodowym. (Innovativeness of Polish Economy against the International Backdrop.) Studia Biura Analiz Sejmowych, (Studies of Bureau of Research Chancellery of the Sejm) 1(25), 9-34. 